\title{
Innovative Policy Schemes to Promote Renovation of Multi-Flat Residential Buildings and Address the Problems of Energy Poverty of Aging Societies in Former Socialist Countries
}

\author{
Dalia Streimikiene ${ }^{1, *(D)}$ and Tomas Balezentis ${ }^{2, *(D)}$ \\ 1 Lithuanian Energy Institute, Breslaujos 3, LT-44403 Kaunas, Lithuania \\ 2 Lithuanian Institute of Agrarian Economics, V. Kudirkos Str. 18-2, 03105 Vilnius, Lithuania \\ * Correspondence: alia.streimikiene@lei.lt (D.S.); tomas@laei.lt (T.B.)
}

Received: 5 March 2019; Accepted: 28 March 2019; Published: 4 April 2019

check for updates

\begin{abstract}
In former socialist countries, urban districts having the lowest building and insulation quality and the highest district heat consumption overlap with low-income and older households, creating a problem of energy poverty and a significant barrier to renovation of multi-flat buildings. Thus, the main challenge centers on fuel poverty in an aging society. This paper analyzes the main barriers to renovation of multi-flat buildings and assesses policies and measures to promote renovation of multi-flat buildings in terms of overcoming these barriers in former socialist countries which are currently EU Member States. Furthermore, it presents a new conceptual framework for developing innovative policies and schemes to promote renovation of multi-flat buildings in the face of the renovation barriers outlined above. The Energy Company Obligation (ECO) model or on-bill financing models can be modified and applied to renovation of multi-flat buildings, based on the UK example. Higher payments for utility bills can be shared among households living in multi-flat buildings that require renovation. As in the case of subsidies for communal services, life-line tariffs can be applied to pay for Energy Company Obligation services. This enables sharing the costs of renovation among apartment owners having different incomes and addresses the principle of social justice.
\end{abstract}

Keywords: energy renovation; multi-flat buildings; energy poverty; ageing society; post-soviet countries

\section{Introduction}

Energy efficiency improvements in building stock is the most important measure to reduce greenhouse gas emissions, because buildings consume more than $40 \%$ of the final energy budget in the EU [1]. However, while energy savings in buildings have huge potential, especially in Central and Eastern Europe with its large stock of old and poorly constructed multi-flat buildings, the process of refurbishment is very slow [2]. Renovation rates in all European Union are estimated to be about 1\% per year [3].

Reducing energy consumption of existing buildings and achieving nearly zero energy buildings (NZEBs) are the core of the Energy Efficiency Directive (EED) and the recast of the Energy Performance of Building Directive (EPBD). To comply with these requirements, EU Member States have to adopt actions to exploit energy savings from the building sector [3,4]. Various policies and measures have been developed and implemented in EU Member States to achieve NZEBs, some of which are innovative enough; however, they cannot solve the problems which hamper fast renovation of multi-flat buildings that have the highest energy-saving potential in new EU Member States from Central and Eastern Europe former socialist countries [5-10]. 
Therefore, this paper focuses on former socialist countries and current EU Member States which have inherited from their socialist past similar problems linked to old and inefficient residential buildings stock [11]. In order to create viable policies to promote renovation of multi-flat buildings, it is important to understand the perspectives of both building owners and institutional investors in order to put in place the most appropriate economic instruments to catalyze the market [12]. Most energy investments in buildings will be made with the building owners' money. On other hand, governments can support and stimulate such decisions with grants, but public funds can only cover a small part of the necessary investment. Other measures may be relevant and even more necessary. Many of these relate to how decisions are made by residents. The main gaps in implementing energy efficiency improvements in multi-flat buildings are linked to the bounded rationality of apartment owners in multi-flat buildings, to organizational problems and high transaction costs, and to imperfectly functioning markets within renovation supply chains. In addition, there is little research on the demand side of multi-flat house renovations and their barriers, especially in post-soviet countries.

Existing studies on energy efficiency improvements in buildings have highlighted a number of technical, organizational, economic, financial, and behavioral barriers that hinder renovation of multi-flat buildings [13-17]. These barriers are especially difficult to overcome for owners of apartments in multi-flat buildings in shrinking and aging communities in post-soviet countries [18]. For example, there are communities in the EU, especially in new member states, that are facing steep declines in birth rates, out-migration of young households, and large stocks of poor-quality, energy-inefficient multi-flat buildings. Therefore, in cities and communities with high concentrations of older residents, "empty-nesters" are often a major impediment to renovation of multi-flat buildings [19].

Several studies report that apartment owners older than 70 years exhibit much lower renovation intensity compared to younger residents [11,20]. In Slovenia, for example, Zoric et al. [20] found that the likelihood of implementing retrofitting of multi-flat buildings is negatively affected by the age of the apartment owner. The inconvenience and disruption created by renovation activities are other important factors explaining the reluctance of apartment owners to undertake renovation activities in their homes [21]. Retired flat owners encounter an additional barrier because the flats are no longer passed down to family members, since the grown children have dispersed and do not plan to return home $[11,12,21-26]$. Contributing to fuel poverty, districts having the lowest building quality and the highest heating consumption often overlap with households whose occupants are older, retired, and low-income [27,28].

Finally, an under-studied problem is the failure of owner-occupants of old, multi-flat buildings to achieve agreement on renovation. This is because, although decision making is a relatively simple process in the case of single owners of residential buildings, it is significantly more complicated when owners are, unintentionally, dependent on each other or have opposing interests [12]. This is a significant problem for schemes aimed at modernizing and improving energy efficiency.

The present paper analyzes the policies and measures enacted to promote renovation of multi-flat buildings in EU member states and assesses them in terms of solving the energy poverty problem of aging societies. The paper's main contribution is its presentation of a new conceptual framework for developing innovative policies to promote renovation of multi-flat buildings and address the barriers to renovation linked to aging populations and fuel poverty.

The first section, based on a literature review, identifies the main barriers to renovation of multi-flat buildings and emphasizes the fuel poverty problem of aging societies; the second section reviews and critically assesses policies and schemes used to promote renovation of multi-flat buildings, taking into account the main barriers to renovation; the third section presents a new conceptual framework for developing innovative policies and measures to overcome the identified barriers.

\section{Methods}

The critical review of recent scientific literature in the field of energy renovation of multi-flat buildings is the main method applied in this review paper. The applied method in this paper consists 
of the following steps (Figure 1): Analysis and identification of the main barriers of energy renovation in multi-flat buildings in former socialist countries that are current EU Member States; Assessment of policies and measures to promote energy renovation of multi-flat buildings in terms of addressing the identified main barriers; Development of the support framework for energy renovation in multi-flat buildings to overcome the main barriers of energy renovation in former socialist countries that are EU Member States; Development of policy implications; Recommendations for future research.

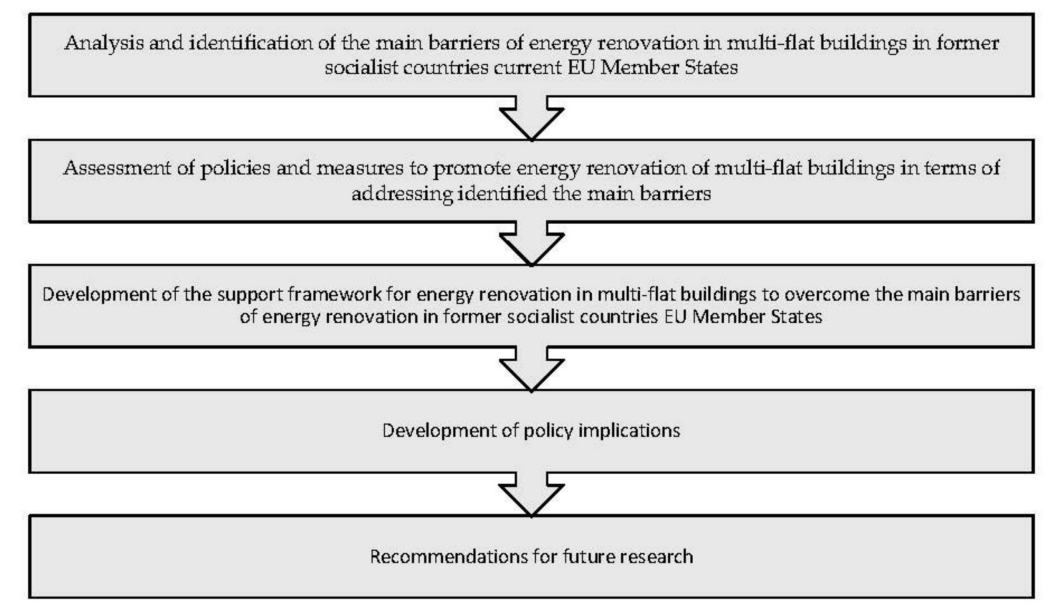

Figure 1. The main steps of the implemented methodology. Source: created by authors.

Therefore, the main criteria for assessment of policies to promote energy renovation of multi-flat buildings is their ability to overcome the most important barriers of energy renovation of multi-flat buildings in former socialist countries that are EU Member States. The strength of applied approach is simplicity and application of both qualitative and quantitative data assessments. The limits are mainly linked to subjectivity of applied approach.

In the following Section 3 the results of critical literature review are presented.

\section{Results}

\subsection{Barriers to Renovation of Multi-Flat Buildings}

In designing policies and measures aimed at promoting renovation of multi-flat buildings, it is necessary to understand why many households are not currently active in this process. Although there are no comprehensive studies in the EU which directly ask people their opinions on the main obstacles to renovating their houses, there are many papers dealing with the barriers to renovation of residential buildings.

The term "barriers to renovation of multi-flat buildings" is based on the concept of an energy efficiency gap $[13,29,30]$ meaning that investments in energy efficiency are considerably lower than what is desirable according to social, economic, environmental, and technological optima. This concept has been widely applied to define the main obstacles to renovation of residential buildings faced by households, societies, and countries.

Itard et al. [31] identified the main barriers to renovation of residential buildings as being a lack of necessary knowledge and appropriate information and a lack of funding and cost-effective retrofitting schemes. Empirical studies within households living in older, poor-quality, inefficient buildings revealed a wide variety of reasons for not undertaking renovation work and showed a wide range of interrelated barriers to renovation: household values and preferences; high cost; poor organization; lack of time; inconvenience; poorly skilled, unreliable, or costly professionals; lack of information about actual savings and benefits; difficulties in reaching a decision by all apartment owners in multi-flat buildings [32]. In a comprehensive study conducted in five European countries, similar barriers to renovation were defined: lack of information on energy savings and anticipated energy savings; high costs; poor policy incentives and often-changing state policies and promotional 
instruments [33]. EST [34] conducted research among non-renovating apartment households and found the following barriers to renovation: lack of timely and relevant targeted information and awareness; poor motivation; high inconvenience; and low affordability. The same findings were obtained in other other studies [35-40].

Some studies analyzed drivers of residential housing renovation. For example, interviews with householders about motivation for renovation indicated different reasons for renovation [36,37]. Motivations are linked to the context in which people find themselves [38]. For example, in countries like Germany [29], which have strong policies to support eco-renovation by providing low-interest loans and generous grant funding, the motivations for renovation are different than in post-soviet countries such as Russia or Lithuania $[29,37]$. Usually the most important issue in all countries is thermal comfort and savings due to energy consumption reduction [29-33,35,41-43].

Several groupings of barriers to renovation of residential buildings have been identified in various studies. Jensen and Maslesa [17] divided renovation barriers for residential buildings into internal barriers linked mostly to the inertia of building owners, and external barriers associated with lack of resources, knowledge, solutions, and agreement among households in the same multi-flat apartment.

The Better Buildings Partnership [44] categorized barriers to residential housing refurbishment into several main areas:

- Commercial barriers or market failure to provide investment in renovation and the inherited split incentives between owners and tenants.

- Barriers in the process of renovation, as there is no defined process on how to designate individuals with the responsibility and authority to identify, plan, and implement renovation of multi-flat buildings.

- Financial barriers linked to the problem of access to and availability of capital funds for the apartment owner, occupier or third party.

- Technology barriers linked to lack of knowledge of available renovation options and other issues associated with implementation of specific renovation activities.

- Policy barriers related to the lack of effective regulation to stimulate the uptake of renovation activities.

- A study by Uihlein and Eder [15] identified the following barriers: uncertainties linked to cost-effectiveness; financial barriers; lack of information and skills; high transaction costs and organizational problems; and context-dependent barriers.

Uncertainties linked to cost-effectiveness are based on the problem that, although cost-effective solutions can be defined and accordingly assessed in specific cases, it does not necessarily follow that the same benefit will be achieved for all types of similar investments in renovation $[12,13,15,27,45,46]$. This is because there is too much conflicting data on the costs and benefits of renovation of multi-flat buildings, often resulting in mistrust of the information $[13,15]$.

Financial barriers are also very important in the context of investment decision making in renovation of residential buildings $[15,27,45]$. Several studies defined the up-front costs as a main barrier to renovation of residential buildings. Other important financial barriers are lack of monetary savings, lack of financial resources [39], and reluctance of low-income and older segments of the population to take out loans [42]. Regarding the landlord/tenant dilemma, both the ability of tenants to pay the rent and their ability to stem the up-front investments of landlords are often directly related to the level of household incomes [11]. Stiess et al. [42] reported that apartment owners with incomes below $€ 1500$ per month are less likely to renovate their apartments compared to owners with incomes greater than $€ 1500$ per month. A study by Zoric et al. [20] found that apartment owners older than 70 years exhibit a lower willingness than younger owners to engage in renovation of multi-flat buildings. The authors showed that the likelihood of implementing retrofitting of multi-flat buildings is negatively affected by the age of the apartment owner [21].

Moreover, apartment owners apply simple "rule of thumb" calculations for decision making in energy efficiency improvement and select measures having such short-term payback periods [14]. 
In addition, some apartment owners have limited access to capital or a high cost of borrowing due to low expected incomes and experience in debt default, or sometimes they are not willing to incur debt, for personal reasons. Low and uncertain property values are also important barriers to renovation of multi-flat buildings, as owners who anticipate selling their property in the future may not feel encouraged to renovate their property.

Apartment owners who do not monitor energy consumption in their buildings are reluctant to make any effort to obtain information or learn about energy renovation possibilities and benefits [3,5]. In addition, there is a lack of experts and resources in the market to deliver this information to consumers.

Logistical barriers include a lack of skilled energy renovation service providers in the market [15]. In addition, there are significant switching costs linked to any change.

Organizational barriers are linked to renovation decision making on a common property, referred to as the principal-agent dilemma [46]. Regarding the owner-occupier dilemma, which is widely described in the scientific literature, lack of knowledge, information and funding are the main barriers preventing private investment in energy renovation, as tenants will not profit from the investment made in rented buildings, and landlords do not derive benefit from the warmer apartments and energy cost savings, as it is the tenants who pay the energy costs $[14,33,39,47-50]$.

The problem of collective decision making linked to multi-flat housing is the most difficult to solve [16]. It is more relevant in cases where the building has a mixture of occupants: part owner-occupants and part tenants. Elderly people or tenants who are expecting to move soon are not eager to engage in renovations. Energy renovations entail considerable disruptions and can be very stressful, especially for elderly persons accustomed to their daily routines. In multi-flat buildings with mixed households, organizational problems may gain even more significance. A short decision time-frame is also an important organizational barrier. The main barriers and measures to overcome these barriers are generalized in Table 1

Table 1. Barriers of large scale energy renovation and policies to overcome them.

\begin{tabular}{|c|c|c|c|}
\hline Categories of Barriers & Definition of Barrier & Examples of Barriers & Measures to Overcome Barriers \\
\hline $\begin{array}{l}\text { Economic/ } \\
\text { financial barriers }\end{array}$ & $\begin{array}{l}\text { Ratio of investment cost to } \\
\text { value of energy savings }\end{array}$ & $\begin{array}{l}\text { Higher up-front costs for large scale energy } \\
\text { renovation; Low income of population; Lack of } \\
\text { access to funds and credits; Lack of } \\
\text { internalization of external energy } \\
\text { production costs }\end{array}$ & $\begin{array}{l}\text { Fiscal and economic instruments such as tax } \\
\text { rebates, subsidized loans, regulatory } \\
\text { instruments. Increase energy price by } \\
\text { internalization of external costs, remove } \\
\text { environmentally harmful energy subsidies }\end{array}$ \\
\hline Hidden costs & $\begin{array}{l}\text { Cost or risks that are not } \\
\text { captured directly in } \\
\text { financial flows }\end{array}$ & $\begin{array}{l}\text { Costs and risks due to potential incompatibilities, } \\
\text { performance risks, high transaction costs etc. }\end{array}$ & $\begin{array}{l}\text { Appliance standards, building codes; } \\
\text { ESCOs, on-bill financing schemes; public } \\
\text { leadership programs }\end{array}$ \\
\hline $\begin{array}{l}\text { Behavioural and } \\
\text { organiza-tional barriers }\end{array}$ & $\begin{array}{c}\text { Behavioural } \\
\text { Characteristics of } \\
\text { individuals and companies } \\
\text { that hinder } \\
\text { implementation of energy } \\
\text { efficiency technologies } \\
\text { and practices }\end{array}$ & $\begin{array}{c}\text { Tendency to ignore small energy saving } \\
\text { opportunities; Organizational failures (e.g., } \\
\text { internal split incentives); Difficulties to make } \\
\text { common decision by flat owners for large scale } \\
\text { renovation of multi-flat building due to } \\
\text { conflicting interests; Non-payment and electricity } \\
\text { theft; Tradition, behavioural patterns and } \\
\text { lifestyles, etc. }\end{array}$ & $\begin{array}{l}\text { Support, information, and voluntary action; } \\
\text { Voluntary agreements by utilities; } \\
\text { Information and training programs for } \\
\text { customers and other actors }\end{array}$ \\
\hline Information barriers & $\begin{array}{l}\text { Lack of information } \\
\text { provided on energy saving } \\
\text { potentials of large scale } \\
\text { energy renovation }\end{array}$ & $\begin{array}{l}\text { Lacking awareness and knowledge of energy } \\
\text { consumers and house owners, building } \\
\text { managers, construction companies, } \\
\text { politicians etc. }\end{array}$ & $\begin{array}{l}\text { Awareness raising campaigns, Training of } \\
\text { building professionals, regulatory-informative } \\
\text { measures, programmes to increase } \\
\text { capabilities of mid-term actors in energy } \\
\text { renovation supply chain }\end{array}$ \\
\hline $\begin{array}{c}\text { Political and } \\
\text { structural barriers }\end{array}$ & $\begin{array}{l}\text { Structural characteristics of } \\
\text { political, economic, energy } \\
\text { system which make } \\
\text { efficiency } \\
\text { investment difficult }\end{array}$ & $\begin{array}{l}\text { Process of drafting local legislation is slow; Gaps } \\
\text { between regions at different economic level; } \\
\text { Insufficient enforcement of standards; Lack of } \\
\text { detailed guidelines, tools and experts; Lack of } \\
\text { incentives for investments; Lack of governance } \\
\text { leadership and policy interest; Lack of } \\
\text { equipment testing/certification; Inadequate } \\
\text { energy service levels }\end{array}$ & $\begin{array}{l}\text { Enhance implementation of standards; } \\
\text { Incentive policy encouraging energy } \\
\text { efficient building design, Enhance } \\
\text { international cooperation and technology } \\
\text { transfer, Public leadership programs }\end{array}$ \\
\hline
\end{tabular}

Source: created by authors. 
Therefore, it is necessary to highlight that the most important problem and barrier to renovation of multi-flat buildings is linked to difficulties of owner-occupants in reaching a collective decision on renovation [12]. This is a problem that has so far received very little attention in the pertinent scientific literature, despite having been highlighted as one of the most critical barriers for multi-flat buildings in several studies $[12,18,51]$. Usually, decision making is quite simple if there is a single owner of the building, but it is very complex if there are multiple owners dependent on each other and who are forced to agree and render a common decision on energy retrofitting of their multi-flat building. The decision-making barriers on energy investments in owner-occupied multifamily buildings are especially acute in post- soviet countries because these types of residential buildings comprise the largest building stocks, even in new EU member states (Lithuania, Latvia, Estonia, Romania, Bulgaria, Hungary, Slovak Republic, Czech Republic, Croatia). In these countries, decisions on energy renovations of multi-flat buildings require the agreement of the majority of residents of the building, and collective decisions are difficult to make since the residents are very different and sometimes have quite conflicting interests. Most residents of multi-flat buildings are not informed about energy renovation options or their costs and benefits as they do not attend residents' meetings. Some owners are afraid that if they sell their apartment, the renovation costs won't be recovered in the sale price [52]. Making decisions on energy renovation can take several years and requires numerous meetings and discussions between residents of multi-flat buildings [12]. The age structure, family size, and income of apartment owners in multi-flat buildings are of major concern [23]. Residents of the same building often have different incomes, as the majority of multi-flat buildings in post-soviet countries have very different apartment sizes, varying from one room to five rooms in the same building. The elderly and persons living alone typically are unwilling to renovate and make any changes [51], due to low incomes and empty nest syndrome. Based on Weinsziehr et al. [18], all households with adults older than 45 and without children are classified as potential empty nests.

Energy poverty is closely linked to an aging demographic and vulnerability of retired persons living alone. Districts with the lowest building quality and insulation have the highest heat consumption and are inhabited by low-income and older households [18,28]. Energy poverty is the term used for households which are unable to afford socially and materially necessitated levels of domestic energy services: heat, hot water, electricity [18,53-55]. Due to increasing energy prices and low household incomes linked to an aging society in post-soviet countries, the energy poverty problem is becoming more and more severe. Low-income households tend to live in less energy-efficient, poorly insulated buildings as they cannot afford better housing or renovation upgrades [54]. This makes low-income households spend a larger share of their income on energy services compared with high-income households, especially in post-soviet countries [56], and increases energy poverty. Even in developed EU economies such as Germany, the problem of energy poverty has increased in recent decades. The energy poverty rate among the German population increased from $12 \%$ to $18 \%$ during the period 2000-2010 and energy prices increased sharply during that decade, creating an even greater energy cost burden for the lower-income population [18]. This issue of energy poverty is mainly attributed to post-soviet legacies-As low-income households living in low-efficiency, district-heated multi-flat buildings are trapped, because changing the supplier or fuel is not possible due to existing legal and technical constraints. Disconnection of individual households from this system is not allowed because it would cause a sharp increase in the price of heat for all other consumers who remained in the system. Thus, households do not have any options to individually reduce their heating costs, a situation which leads to payment delays, indebtedness, and reduced consumption of food and other necessary goods [27].

In view of the differences among apartment owners in the same building in terms of age, income and other characteristics, one can notice that it is very difficult to reach a decision concerning renovation, especially if this decision requires approval of a large majority of apartment owners, for example 67\% in Romania [57] and Bulgaria [12], 75\% in Germany and Czech Republic [23]. 
According to Heiskanen et al. [58], most EU member states typically require assent from more than $50 \%$ of apartment owners (Austria, Finland, France, Spain, Italy).

Various categories of barriers to renovation of multi-flat buildings are overlapping and mutually reinforcing. There are many risks and uncertainties associated with energy renovation, and apartment owners may incur even higher risks for new solutions than the risks of the status quo, given the fragmented and underdeveloped market for energy renovations and associated financial services. Most significantly, these barriers to energy renovation of multi-flat buildings, or the reasons for inaction, are multiple and interrelated, depend on household type, and vary over time. In addition, in the EU, the aging society, fuel poverty and shrinking cities create what Rittel and Webber [59] referred to as a 'wicked problem'. 'Wicked problems' are problems of high complexity which usually cannot be solved by linear solutions alone and require innovative ways and packages of policies and measures (e.g., [60]).

Considering the high complexity of this wicked problem, this paper analyzes policies and measures to promote renovation of multi-flat buildings, taking into account the barriers identified above and the suitability of the policies and measures in place to overcome these barriers.

\subsection{Assessment of Policies and Measures to Promote Renovation of Multi-Flat Buildings}

Renovation of multi-flat buildings is the main measure to increase energy efficiency in residential buildings and deliver important energy savings to households. The energy demand in buildings can be reduced by increasing the energy performance of residential buildings through improvements in thermal envelope function and the installed heating system. The present paper focuses on policies and measures to promote energy-efficient renovation of multi-flat buildings, which is the main problem of many post-soviet countries, especially in cool climate zones.

A review of the most important measures for motivating apartment owners to implement energy-efficient renovation of residential buildings shows that these measures have brought only limited success in most countries (Germany, UK, Denmark, US, Japan) where such studies were conducted [23-25,61-67].

The main measures to promote renovation of multi-flat buildings can be grouped into the following five broad classes: (1) information and advice; (2) energy and $\mathrm{CO}_{2}$ taxes; (3) financial incentives; (4) access to capital; and (5) minimum standards.

Information and advice play an important role in supporting consumers in the face of information failures. Due to incomplete and asymmetric information [30], high uncertainty, and high hidden costs, apartment owners are reluctant to undergo renovation of multi-flat buildings. Programs providing information and advice have had varying results but have not been fully able to facilitate and reinforce renovation of multi-flat buildings. Though energy certificates and labels have been developed to support households in making the right decisions by providing reliable information at no cost, they also seem to be an effective signaling device that is capitalized into home prices. For EU member states, energy performance certificates (EPC) are mandatory for buildings and must be shown to prospective renters and buyers; however, the new literature on energy labeling effectiveness in the EU concluded that energy labels are not being widely applied by customers in various EU member states as homeowners in general feel that energy performance certificates provide only very general and trivial information, i.e., that the labels do not provide any new recommendations that the homeowner would not have expected him/herself [62].

Feedback programs are also an important advice measure. Energy audits are useful as they can ensure provision of personalized information about energy consumption reduction potential in apartments; however, the empirical results show that the effectiveness of energy audit schemes is rather mixed. Some studies find some energy savings due to energy audits, but others show no impact or even an increase in energy usage [67]. Smart meters and other advanced online monitoring systems present a good opportunity to increase feedback to consumers, since they can provide persistent and real-time information. Building-monitoring systems [67] or the installation of metering devices which 
track "voluntary" energy consumption for electricity, heating, cooling, and domestic hot water of individual households necessary for energy cost distribution among apartments is a good example of a feedback program. However, the impact of feedback programs on an occupant's decision to renovate is limited by other barriers to multi-flat building renovation.

Taxes on energy or $\mathrm{CO}_{2}$ that raise the cost of energy send price signals to households to implement more energy efficient and advanced technologies or behavioral innovations. Some EU member states with high energy efficiency standards, such as Germany [39] and Denmark [62] and corresponding high environmental and energy taxes, have populations that are very conscious of saving energy. However, in post-soviet countries, where the taxes on energy are significantly lower because of lower income levels, the taxes do not stimulate renovation. Moreover, low-income households in post-soviet countries receive VAT reductions for district heat, which further discourages renovation.

Financial incentives such as supplier obligations, tax incentives, grants, soft loans, and feed-in tariffs force consumers to implement measures by lowering the cost faced by households; however, their impact on flat-owners' decision making to renovate multi-flat apartment is not proved empirically. Energy Efficiency Obligations (EEO), Energy Supply Obligations (ESO), or Energy Company Obligations (ECO), which require energy suppliers or utilities to achieve energy efficiency improvements in buildings, have been used widely across Europe but have not necessarily delivered their targets [25]. EEOs, together with tradable white certificates, are being applied in the United Kingdom, Denmark, France, and Italy. There is a plan to implement EEOs in Poland; however, in general, ESOs are not popular in other post-soviet countries due to soviet legacies of district heat systems, as described above.

The implemented ECOs exhibit a wide diversity of design and different outcomes. The ECO model applied in the UK focuses on implementation of high-cost renovation measures such as wall insulation and is targeting low-income households via specific obligations (Carbon Saving, Carbon Saving Communities, and Affordable Warmth Obligations). The UK ECO was initiated in 2013 with the aim to reduce energy consumption and address fuel poverty. It was scheduled to continue until 2017. The ECO establishes the legal obligations for energy suppliers to implement energy efficiency improvements in the residential sector and operates together with the Green Deal. The idea of the Green Deal is to help low-income households renovate their apartments by creating an opportunity to pay renovation costs not upfront but placing them on utility energy bills. The empirical findings indicate that this scheme is not the best instrument to realize energy savings in existing buildings and is very expensive compared with the achieved energy savings [68]. In addition, this scheme does not overcome the barriers to common decision making in the renovation of multi-flat buildings whose residents have different characteristics. Therefore, ECO schemes need to be tailored according to their national context.

Tax incentives such as rebates typically compensate consumers for some share of energy renovation costs. Like grants, tax incentives can be effective but are susceptible to free-riding. As rebates are usually paid back to the consumer after the work has been completed, they are often found to be taken up by higher-income households who can cover upfront costs. Similarly, a reduced rate of VAT of $5 \%$ in the UK and $9 \%$ in Lithuania applies to energy-saving products and also to residential energy use, providing more support to higher-income segments of the population that have large apartments and use more heat.

Measures to improve capital access, such as loan guarantees or low-cost loans and preferential mortgage rates, can facilitate large-scale renovation that has high upfront costs, and may be especially suited to low-income apartment owners who have limited access to capital. However, lack of financing is not the primary reason hampering large-scale renovation. Financing is needed just when the product is sold, so grants covering part of the cost of energy renovation usually are also required to accompany such loans.

Loan schemes are typically 'softened' by offering zero- or low-interest rates. These are often implemented through public-private partnerships, with the government guaranteeing financial support to the bank and requiring the financial institution to offer a preferential interest rate 
for the loans made to households for large-scale renovation. An alternative approach is for government to provide a guarantee which shares the credit risk with financial institutions, to scale-up private investments [69].

The Green Deal scheme mentioned above was designed to defer upfront energy renovation costs. Implemented in 2013, it was hailed as a major regulatory innovation to achieve "a revolution in British property" and put "consumers back in control." A main feature of the Green Deal was its "golden rule", in which the achieved energy savings for a 25-year period must be greater than the cost of the investment [69]. The innovativeness of the support scheme for renovation of multi-flat buildings in the UK was a combination of loans and ESO intended to work together: where measures cost too much to meet the conditions for accessing Green Deal loans, it was expected that homeowners would 'blend in' contributions from energy suppliers through an ESO. The Department of Energy \& Climate Change, which implemented this scheme, also expected suppliers to encourage consumers to pay partly for ESO measures using Green Deal financing to minimize their costs. Though the Department of Energy \& Climate Change spent $£ 240$ million on the Green Deal, it did not generate additional energy savings because the scheme did not persuade enough people to implement large-scale energy renovations and was deemed by State Audit to have not been of value for the money [59]. In addition, though capital costs can be covered by the Green Deal through pay-as-you-save schemes, the Green Deal and similar schemes have other drawbacks such as lack or asymmetry of information and low access to funds [70].

Therefore, pay-as-you-save schemes will not overcome barriers to energy renovation for low-income families because such consumers would have to divert a significant fraction of the energy savings to repay the cost of the retrofit in their utility bills.

Minimum performance standards or building codes are widely used to regulate the standards to which buildings, appliances, or boilers must comply. These take the least-efficient products off the market, reframing consumers' choices. Many countries also use standards at the point of renovation, for example Denmark, Sweden, and Germany. There is no clear evidence for the effectiveness of these policies to date [70].

All analyzed measures do not provide effective results regarding the renovation of multi-flat buildings because the main barriers are not being properly addressed by these schemes. If programs are transparent and sufficiently simple from a household's perspective, then they are more likely to achieve their intended impacts. However, there is no one-size-fits-all policy for energy renovation due to over-complexity of the barriers and problems linked to specific countries. Therefore, the specific scheme should be elaborated by taking into account the need to target different stakeholders in the energy renovation process. It is necessary to consider the consumer journey and provide a streamlined application process.

Attracting consumer trust is also important in making sustained progress in energy renovation. The trusted intermediaries to make energy renovation programs well aligned and to manage their implementation are very important. Many countries have a designated energy agency that performs this function. There is also a need for a skilled energy renovation service supply chain. Germany, for example, has developed an energy renovation supply chain of trusted, highly qualified engineers [70].

The delivery method for these schemes can increase consumer trust. Targeting schemes at specific geographical areas, such as neighborhoods, can improve take-up, by engaging with wide social networks that spread the message and recommendations between trusted parties (friends, family members, community members, and neighbors). The use of organizations with which consumers already have a relationship can help with trust and facilitate delivery [69].

Communication and marketing skills are important in making the policy measures work. Communication will provide the best results when it conveys a direct and simple message to the target group by applying a streamlined approach across all policies and schemes to support energy renovation [64]. In addition, the effectiveness of a policy is stronger if it is combined and harmonized with other policies targeting the same issues, but redundancies and overlapping of policies can lead to inefficient allocation of resources [66]. 
Other policies to encourage installation of microgeneration renewable technologies such as the fed-in-tariffs (FIT) are also linked to renovation of multi-flat buildings [24].

In Table 2 the policies and measures to promote renovation of multi-flat buildings are systematized and evaluated.

Table 2. The policies and measures to promote renovation of multi-flat buildings implemented in various countries.

\begin{tabular}{|c|c|c|}
\hline Policies and Measure & Evaluation & Country \\
\hline $\begin{array}{l}\text { Regulatory measures: communicative and } \\
\text { information instruments, regulatory tools } \\
\text { such as products and appliance standards, } \\
\text { building codes, monitoring programmes, } \\
\text { ESCOs involvement, public } \\
\text { leadership programs; }\end{array}$ & $\begin{array}{l}\text { These measures for motivating } \\
\text { apartment owners to implement energy } \\
\text { renovation of multi-flat buildings have } \\
\text { provided for insignificant success. } \\
\text { These instruments fail to address } \\
\text { adequately the barriers in apartment } \\
\text { owners decision making in } \\
\text { energy renovation. }\end{array}$ & $\begin{array}{c}\text { Germany, UK } \\
\text { Denmark, Italy, France }\end{array}$ \\
\hline $\begin{array}{l}\text { Progressive regulation measures for higher } \\
\text { renovation standards; subsidies only for } \\
\text { energy renovation going beyond a } \\
\text { minimum standard }\end{array}$ & $\begin{array}{l}\text { These measures do not provide good } \\
\text { results and may not work out well in } \\
\text { the future as costs of renovating to high } \\
\text { standards will rise exponentially and } \\
\text { the amount of additional energy savings } \\
\text { will rise only modestly. }\end{array}$ & Germany \\
\hline $\begin{array}{c}\text { Market based instruments such as White } \\
\text { Certificates or Energy } \\
\text { Performance Certificates }\end{array}$ & $\begin{array}{l}\text { White certificates or Energy } \\
\text { Performance Certificates are a } \\
\text { mandatory requirement for all } \\
\text { dwellings sold or rented in the region } \\
\text { but have had little impact on decision } \\
\text { making or price negotiation so far in } \\
\text { adopted countries. These measures also } \\
\text { do not address the organizational } \\
\text { barriers of decision making on energy } \\
\text { renovation of multi-flat buildings }\end{array}$ & England and Wales \\
\hline Fiscal measures: $\mathrm{CO}_{2}$ and energy taxes & $\begin{array}{l}\text { High energy taxes applied in Germany } \\
\text { and Sweden have impact on energy } \\
\text { saving behavior of households however } \\
\text { there are no countries having fully } \\
\text { internalized external costs of } \\
\text { energy production }\end{array}$ & Germany, Sweden \\
\hline $\begin{array}{c}\text { Financial measures: Programs that provide } \\
\text { subsidies and soft loans for } \\
\text { energy renovation }\end{array}$ & $\begin{array}{l}\text { The effectiveness of these programs is } \\
\text { low due to free-riders, i.e., house } \\
\text { owners receiving the subsidy which } \\
\text { would also have renovated without the } \\
\text { subsidy their apartments. In UK Great } \\
\text { Deal programme was implemented } \\
\text { together with ESCO. }\end{array}$ & Germany, UK, France \\
\hline $\begin{array}{l}\text { Policy packages which seek to address } \\
\text { multiple financial barriers at the same time }\end{array}$ & $\begin{array}{l}\text { Such policies are likely to be quite } \\
\text { effective however there are no results } \\
\text { about their effectiveness so far. }\end{array}$ & EU, USA, Japan \\
\hline
\end{tabular}

Source: created by authors.

However, it is necessary to stress that the problems linked to energy poverty and difficulties of different income-level owner-occupants in reaching a collective decision on renovation cannot be solved by the policies and measures described above. There are additional measures to support low-income households living in energy poverty which are also ineffective and cannot deal with the energy-gap problem. Support by paying the energy bills of the low-income segment can lock households into fuel poverty by removing incentives to make investments in energy renovation. Also, the income saved may be spent by households on other goods instead of investing in energy efficiency $[28,70]$. There are other measures to help low-income households and tackle energy poverty 
by reducing high district heat costs such as the reduced VAT payable on district heat. However, there are many arguments against these as they can be treated as environmentally harmful subsidies and also because of their limited coverage, high administration costs, and use by higher-income households with large apartments and consequently higher energy consumption. All these measures distort markets and divert financial resources away from long-term solutions such as large-scale energy renovation of multi-flat buildings [28,70].

A new conceptual framework is necessary to address the energy poverty problem and especially the linked problems of collective decision making while taking into account differences among apartment owners in terms of household size, age, habits, income, education, knowledge, etc. Innovative policies and measures should be developed by considering the weaknesses of current measures to address fuel poverty, especially of the aging population.

It is necessary to describe the meaning of "innovation" in this context. In most cases, "innovation" is used to define new technology or new products. Here, the term innovation is used to include novelty in several domains: product innovations, innovative practices (specific ways of doing specific tasks), and process innovations (how implementation of the support scheme is organized). Without innovation in these three domains, well-established products and services linked to large-scale energy renovation may have very little penetration into the market because they are not covered by the mainstream practices and processes of the existing energy renovation industry, and thus would fail to overcome the technical, financial, economic, and behavioral barriers preventing the take-up of large-scale energy renovation options for obsolete multi-flat buildings.

It is also necessary to stress that all existing instruments do not adequately address such important organizational barriers as the complications of different flat-owners in making a common decision on renovation of multi-flat buildings due to their conflicting interests and different demographics. These problems and barriers are even more severe in the context of energy poverty and aging society in post-soviet, cold-climate countries, as noted above (e.g., reliance of low-income households on district heating without other fuel options). Large-scale renovation of these buildings is hampered by other barriers, such as access to capital, which are not well addressed by policy instruments in post-soviet countries. In addition, these policies and measures will not work in the future either, as the costs of retrofitting to higher standards rise exponentially accompanied by only incremental energy savings.

\section{A New Conceptual Framework for Developing Innovative Policies and Measures to Promote Renovation of Multi-Flat Buildings}

Energy affordability is an important issue and various schemes can be applied to guarantee energy supply to the low-income segment of the population. In the pricing of energy and other utilities such as water and heat, communication services etc., there is frequently a conflict between the goals of efficiency and those of equity. Efficiency dictates that the prices should be set at the level of the long-run marginal cost of supply and all consumers for whom this long-run marginal cost (LRMC) is the same should pay the same price. Equity, on the other hand, demands that prices should somehow be related to affordability; hence the poor should pay less per unit of services than the rich. This conflict is not new in the policy field and is something many countries have wrestled with. Even the more industrialized nations such as EU member states or the USA provide some relief to poor households to cover their utilities costs. In developing countries, a common practice is to have block tariffs, with the lowest block having a very low price and each additional block having a higher price. Such tariffs are called life-line tariffs. These are very popular in developing countries and many of them have rates with one or more blocks.

The welfare costs of our proposed scheme are provided in Figure 2 which assumes two block rates, with the higher rate being set so that the utility recovers the full cost of the service. There are two categories of consumers: "poor" and "rich". With the price of energy equal to the LRMC, poor households consume $q_{p o}$ and rich households $q_{r o}$. The solution is efficient in the sense that 
consumer surplus is maximized and no households can be made better off without some other households being made worse off. In economic terminology the solution is 'Pareto efficient'.

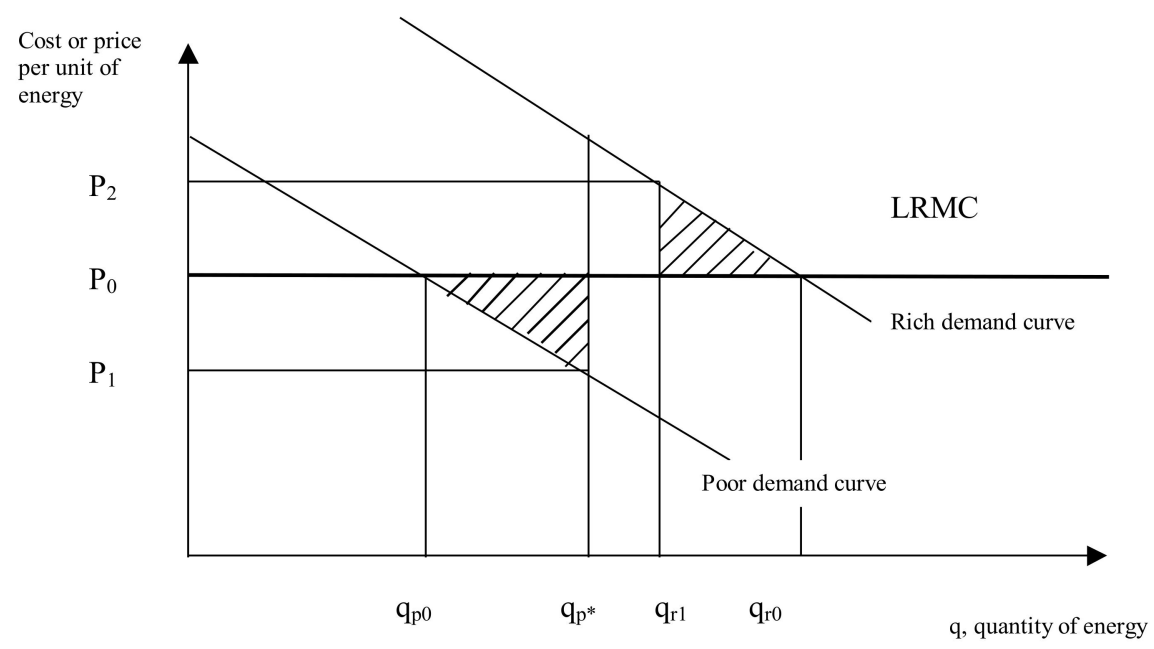

Figure 2. Welfare Pricing of Energy.

This Pareto efficient solution may be unsatisfactory for two reasons. First the share of income spent on energy by poor households may be too high, leaving them without enough money for other necessities. Second, the amount of energy they consume $\left(q_{p o}\right)$ may be considered insufficient for their social needs [71].

The analysis of lifeline rates can be carried out as follows. In Figure 2, suppose that the socially desired consumption for poor households is $q_{p}$. At the same time the utility must cover the costs of provision of the energy. This may be achieved by

1. having a lifeline rate of $P_{1}$ for consumption up to $q_{p} *$;

2. setting tariffs at level $P_{2}$ for consumption above $q_{p} *$.

The welfare losses associated with these changes are shown as the two shaded areas, viz.:

$$
\frac{1}{2}\left(P_{0}-P_{1}\right) \times\left(q_{P_{*}}-q_{P 0}\right)+\frac{1}{2}\left(q_{r o}-q_{r 1}\right) \times\left(P_{2}-P_{0}\right)
$$

Of course, the tariff has to be designed so that the revenue is equal to the cost of supply:

$$
2 P_{1} \times q_{P *}+\left(q_{r 1}-q_{p *}\right) \times P_{2}=P_{0}\left(q_{P *}+q_{r 1}\right)
$$

The design of the tariff may be further complicated by the need to keep overall expenditure for poor households below a certain level:

$$
\frac{q_{P *} \times P_{0}}{Y_{P}} \leq \alpha
$$

where $Y_{p}$ is the income of the poor households and $\alpha$ is the declared acceptable share of energy expenditure.

The design problem may therefore be stated as follows:

Select $P_{1}, P_{2}$ such as to minimize (1) subject to (2) and (3).

Furthermore, without doing the analysis with quantitative data, it is not possible to say precisely what the welfare costs of the scheme will be. Nevertheless, there is some indication that these costs will be moderate. The main reason for this view is that consumer surplus gains and losses to different groups are not of equal value in welfare terms. In this scheme, the poor gain consumer surplus and the rich lose consumer surplus (the utility is left neutral). If a dollar of loss to the rich is valued less than a dollar of gain to the poor, then the net cost could be quite small [71]. 
The life-line approach can be applied for implementation of large-scale retrofitting schemes which are too expensive for low-income segments of the population, especially in post-soviet countries. As detailed above, many urban districts with the lowest energy-efficient buildings and the highest heating consumption overlap with low-income and older households, creating problems of energy poverty and barriers to renovation of multi-flat buildings.

The issues relating to the willingness of households to participate in such schemes are very important to develop effective retrofitting schemes and ensure mass participation in different districts and across different socio-economic and age groups of the population [72,73]. In addition, implementation of the renovation process of a multi-flat building is a complicated process causing inconvenience and disruption and requiring considerable logistical and organizational skills. Therefore, the important gaps in implementing energy efficiency improvements in multi-flat buildings are linked to bounded rationality of flat owners, to organizational problems and high transaction costs. However, the biggest problem relates to the difficulties of owner-occupants in the same multi-flat building reaching a collective decision due to varying, often conflicting, household demographics [74,75].

The most important thing is to ensure that one actor takes the main responsibility of all the energy renovation needs for a multi-flat building. The ESO model can be applied for dealing with organizational issues of renovation of multi-flat buildings. An ESO offers energy services to households such as energy supply, installation of energy-efficient equipment, refurbishment of buildings, maintenance and operation, including facility management [76]. The ESO also assumes the technical risks of the necessary investment in energy renovation and receives financial benefits from that risk taking. The main revenues of an ESO business model are linked to the achieved reduction of either energy costs or energy consumption. Therefore, large-scale renovation of multi-flat buildings can also be classified as an energy service business [76-78]. A service business can be included in the modified ESO model for post-soviet countries, which do not yet have any experience with the ESO model in the residential sector. The modified ESO services can include all the energy renovation work necessary for multi-flat buildings, e.g., engineering, financing, product supply and installation, ensuring all permits, collection of agreements from the flat owners, and arranging the financial guarantees for the energy renovation period. Other services can be included in the ESO model such as energy auditing, consulting, metering, operation and maintenance after the energy renovation of the multi-flat building.

In large-scale energy renovations, financing is one of the main issues to be resolved. The ESO should at least define and select the financing institution and negotiate the contracts with it. The major problem of applying an ESO to the residential sector is in confronting the common decision-making of flat owners in a multi-flat building. While laws demand that a majority of flat owners agree, the collecting of household assent and signatures can require considerable effort on the ESO side. This problem can be mitigated by applying an on-bill financing system as it can be implemented more easily.

On-bill tariffs are a scheme for charging apartment owners for large-scale energy renovations of multi-flat buildings as a service by the utility [76]. The energy renovation will allow a lower overall utility bill due to the energy savings achieved [77]. This model was developed to target a single-family household [77] but it could be easily extended to multi-flat buildings. There are examples of such schemes implemented in the United States for multi-flat buildings [79]. The power utility can involve additional partners to ensure financing of large-scale energy renovation, such as government bodies or financial institutions [80]. Such programs can be successful when they are straightforward and the contractors are able to collect payment for their services quickly $[76,81]$.

Therefore, regional and state authorities can require utilities in the district heat sector to implement ambitious energy efficiency improvements in residential multi-flat buildings and ensure the financial viability of large-scale renovations by developing appropriate district heat tariffs. [82,83]. Such district heat tariffs have to cover the costs of heat production, supply and distribution, and the massive need for modernization of multi-flat buildings in district heat supply networks. This on-bill financing 
business model can be suitable for post-soviet countries in view of the trapped energy poverty issues described above; however, these tariffs would dramatically increase customer payments for heat, though they are very high even now.

The problem of high tariffs can be addressed by life-line rates which would allow equity issues to be addressed. Of course, comprehensive studies are necessary to assess the willingness of different household groups to pay for renovation services in the ESO business model and for on-bill tariffs. The utility company in both cases would be the central organization in this retrofitting scheme [81].

"Middle actors" in the energy renovation industry should also be considered. The renovation of multi-flat buildings is mainly the preserve of small and medium-sized enterprises in all countries, which include construction workers, builders, plumbers, heating and electricity engineers, architects and designers, project managers etc. It can be argued that measures aimed at the energy renovation market will impact the entire value chain and could be very effective in scaling up energy renovation activities nationwide. If employers in energy renovation industries are trained and motivated to save energy, then this knowledge would be present and applied during renovation of residential buildings. These energy renovation market participants are called "intermediaries" in the innovative technologies and products adoption process, and as such are expected to be engaged in retrofitting services if their clients such as energy utilities demand it and even more if it is mandated by law.

\section{Conclusions and Policy Implications}

There are many barriers preventing energy renovation of multi-flat buildings though improved energy efficiency: lack of access to capital by apartment owners and government; lack of knowledge of large-scale renovation issues; split initiatives; difficulties of owner-occupants in reaching a collective decision due to different ages, incomes, and sizes of households in the same multi-flat buildings. These barriers are increasingly becoming more difficult to overcome due to increasing fuel poverty of aging, shrinking populations in cities of post-soviet countries.

Both top-down and bottom-up strategies to promote renovation of multi-flat buildings are necessary. The development of new instrument packages and policy reforms targeted specifically at owner-occupied multifamily buildings is an urgent priority if Europe is to meet its 20-20-20 targets. The current top-down strategies initiated by governments can support and stimulate investments in renovation of multi-flat buildings with tax credits, grants etc., but available public funds can provide only a small share of the necessary investment and are not enough to create initiatives for renovation.

Therefore, it is necessary to elaborate targeted, well-balanced and attractive innovative schemes in order to stimulate the market. The provision of a structured and moderated decision process and tailored financial services provided by one principal actor who organizes all the renovation needs could facilitate the process of renovation of multifamily buildings from the bottom up.

Other innovative practices and processes are linked to "middle actors" in the energy renovation industry. There are important middle-out factors, especially in the energy renovation supply chain, that affect all stakeholders in the energy renovation process, including the upstream policy makers and the downstream consumers. Therefore, energy renovation professionals in the building sector can affect the outcomes of upstream (new policies and schemes), downstream (ESO, on-bill financing by utilities etc.), and lateral (new participants, new skills and new business models in the energy renovation supply chain) actions. This "middle-out" approach as a complement to "top-down" and "bottom-up" strategies should be taken into account to achieve better results in energy renovation as it circumvents many interlinked and self-enforcing barriers.

Legal and regulatory instruments could provide additional requirements for minimum reserve funds for multi-flat building renovation based on the thermal quality of the buildings. However, the most important issue is to solve the problem of collective decision making, taking into account the different demographics of apartment owners.

The ECO model or on-bill financing models can be modified and applied to renovation of multi-flat buildings, based on the UK example. Higher payments for utility bills can be shared among households 
living in multi-flat buildings that require renovation. As in the case of subsidies for electricity, water, and other communal services, life-line tariffs can be applied to pay for ECO services. This enables sharing the costs of renovation among apartment owners having different incomes and addresses the principle of social justice.

The proposed new scheme based on life-line tariffs for renovation was not empirically tested. For implementation of this scheme, it is necessary to assess the willingness of apartment owners to pay for retrofits of multi-flat buildings and to share costs based on income and such other important attributes as financial support from the government, level of improved energy efficiency after renovation, reduced maintenance costs, better thermal comfort etc.

For this reason, the future research will entail assessing the willingness of households to pay for renovation of multi-flat buildings in a selected post-socialist country (Lithuania) and, based on this assessment, developing a proposal for life-line tariffs for renovation via an ECO or utility according to the on-bill financing model. The best business model for Lithuanian conditions will be selected and necessary modifications will be proposed.

Author Contributions: D.S. conceptualized this manuscript; T.B. consolidated the literature reviewer; D.S. and T.B. reviewed the manuscript and assisted in writing and finalizing the manuscript.

Funding: This research was funded by a grant (No. S-MIP-17-131) from the Research Council of Lithuania.

Conflicts of Interest: The authors declare no conflict of interest.

\section{References}

1. European Commission. Communication from the Commission to the European Parliament, the Council, the European Economic and Social Committee and the Committee of the Regions. An EU Strategy on Heating and Cooling, SWD; European Commission: Brussels, Belgium, 2016.

2. D'Agostino, D.; Zangheri, P.; Castellazzi, L. Towards Nearly Zero Energy Buildings in Europe: A Focus on Retrofit in Non-Residential Buildings. Energies 2017, 10, 117. [CrossRef]

3. Buildings Performance Institute Europe (BPIE). Europe's Buildings under the-A Country-by-Country Review of the Energy Performance of Buildings; BPIE: Brussels, Belgium, 2011.

4. Zebra 2020. Nearly Zero Energy Building Strategy 2020-Strategies for a Nearly Zero-Energy Building Market Transition in the European Union. 2014. Available online: http:/ /zebra2020.eu/website/wp-content/uploads/ 2014/08/ZEBRA2020_Strategies-for-nZEB_07_LQ_single-pages-1.pdf (accessed on 23 March 019).

5. ODYSSEE-MURE. Energy Efficiency Trends and Policies in the Household and Tertiary Sectors-An Analysis Based on the ODYSSEE and MURE Databases. 2019. Available online: http://www.odyssee-mure.eu/ publications/br/energy-efficiency-in-buildings.html (accessed on 23 March 2019).

6. Castellazzi, L.; Zangheri, P.; Paci, D. Synthesis Report on the Assessment of Member States' Building Renovation Strategies; EUR 27722 EN; Publications Office of the European Union: Luxembourg, 2016.

7. Zacà, I.; D'Agostino, D.; Congedo, P.M.; Baglivo, C. Assessment of cost-optimality and technical solutions in high performance multi-residential buildings in the Mediterranean area. Energy Build. 2015, 102, 250-265. [CrossRef]

8. Buildings Performance Institute Europe (BPIE). Implementing Nearly Zero-Energy Buildings (nZEB) in Bulgaria—Toward a Definition and Roadmap; Building Performance Institute Europe BPIE: Brussels, Belgium, 2012.

9. Buildings Performance Institute Europe (BPIE). Implementing Nearly Zero-Energy Buildings (nZEB) in Poland-Toward a Definition and Roadmap; Building Performance Institute Europe BPIE: Brussels, Belgium, 2012.

10. Buildings Performance Institute Europe (BPIE). Implementing Nearly Zero-Energy Buildings (nZEB) in RomaniaToward a Definition and Roadmap; Building Performance Institute Europe BPIE: Brussels, Belgium, 2012.

11. Abolghasemi, M.; Ismail, S.; Mohd Sharif, N.B.; Kookhdan, A.R.; Mardani, A. Enhancing the Performance of Residential Construction Project Through Stakeholder Satisfaction: The Application of Structural Equation Modelling (SEM). Tran. Business Econ. 2018, 17, 107-137.

12. Heiskanen, E.; Atanasiu, B.; Kranzl, L. Energy renovation of EU multifamily buildings: Do current policies target the real problems? In Proceedings of the ECEEE 2013 Summer Study, Belambra Les Criques, France, 3-8 June 2013; pp. 1485-1496. 
13. Golove, W.; Eto, J. Market Barriers to Energy Efficiency: A Critical Reappraisal of the Rationale for Public Policies to Promote Energy Efficiency; Office of Scientific and Technical Information (OSTI): Washington, DC, USA, 1996.

14. Wittmann, T.; Morrison, R.I.; Bruckner, T. A Bounded Rationality Model of Private Energy Investment Decisions. SSRN Electron. J. 2006. [CrossRef]

15. Uihlein, A.; Eder, P. Towards Additional Policies to Improve the Environmental Performance of Buildings. In European Commission Joint Research Centre, Institute for Prospective Technological Studies. JRC Scientific and Technical Reports EUR 23775 EN; RePEc: Brussels, Belgium, 2009.

16. Lujanen, M. Legal challenges in ensuring regular maintenance and repairs of owner-occupied apartment blocks. Int. J. Law Built Environ. 2010, 2, 178-197. [CrossRef]

17. Jensen, P.A.; Maslesa, E. Value based building renovation-A tool for decision-making and evaluation. Build. Environ. 2015, 92, 1-9. [CrossRef]

18. Weinsziehr, T.; Grossmann, K.; Groger, M.; Bruckner, T. Building retrofit in shrinking and agening cities: A case-based investigation. Build. Res. Inf. 2017, 45, 278-292. [CrossRef]

19. Herfert, G.; Lentz, S. New Spatial Patterns of Population Development as a Factor in Restructuring Eastern Germany. In Restructing Eastern Germany; Springer Nature: Basingstoke, UK, 2007; pp. 91-109.

20. Zoric, J.; Filippini, M.; Hrovatin, N. Determinants of Energy-Efficient Renovation Decisions of Slovenian Homeowners. In Proceedings of the IAEE Conference, Venice, Italy, 9-12 September 2012.

21. Karvonen, A. Towards systemic domestic retrofit: A social practices approach. Build. Res. Inf. 2013, 41, 563-574. [CrossRef]

22. Ma, Z.; Cooper, P.; Daly, D.; Ledo, L. Existing building retrofits: Methodology and state-of-the-art. Energy Build. 2012, 55, 889-902. [CrossRef]

23. Bürger, V. The assessment of the regulatory and support framework for domestic buildings in Germany from the perspective of long-term climate protection targets. Energy Policy 2013, 59, 71-81. [CrossRef]

24. Janda, K.B.; Fawcett, T.; Killip, G. Innovation in low-energy residential renovation: UK and France. Proc. Inst. Civ. Eng. 2014, 167, 117-124.

25. Labanca, N.; Suerkemper, F.; Bertoldi, P.; Irrek, W.; Duplessis, B. Energy efficiency services for residential buildings: Market situation and existing potentials in the European Union. J. Clean. Prod. 2015, 109, 284-295. [CrossRef]

26. Guerra-Santin, O.; Boess, S.; Konstantinou, T.; Herrera, N.R.; Klein, T.; Silvester, S. Designing for residents: Building monitoring and co-creation in social housing renovation in the Netherlands. Res. Soc. Sci. 2017, 32, 164-179. [CrossRef]

27. Herrero, S.T.; Ürge-Vorsatz, D. Trapped in the heat: A post-communist type of fuel poverty. Energy Policy 2012, 49, 60-68. [CrossRef]

28. Boardman, B. Fixing Fuel Poverty: Challenges and Solutions; Earthscan: London, UK, 2010.

29. Jovovic, R.; Simanaviciene, Z.; Dirma, V. Assessment of Heat Production Savings Resulting from Replacement of Gas with Biofuels. Transform. Bus. Econ. 2017, 16, 34-52.

30. Jaffee, A.B.; Stevins, R.N. A energy-efficiency gap. What does it mean? Energy Policy 1994, 22, 804-810. [CrossRef]

31. Itard, L.; Meijer, M.; Vrins, E.; Hoiting, H. Building Renovation and Modernisation in Europe: State of the Art Review; ERABuild Final Report; Delft University of Technology (TU Delft): Delft, The Netherlands, 2008.

32. Mallaband, B.; Haines, V.; Mitchell, V. Barriers to Domestic Retro T-Learning from Past Home Improvement Experiences; Retrofit: Salford, UK, 2012.

33. Beillan, V.; Battaglini, E.; Goater, A.; Huber, A.; Mayer, I.; Trotignon, R. Barriers and Drivers to Energy Efficient Renovation in the Residential Sector Empirical Findings from Five European Countries. In Proceedings of the European Council for an Energy Efficient Economy, Summer Study, Hyeres, France, 6-11 June 2011; pp. 1083-1093.

34. EST. Sustainable Refurbishment; Energy Saving Trust: London, UK, 2010.

35. Consumer Focus. What's in It for Me? Using the Benefits of Energy Efficiency to Overcome the Barriers; Consumer Focus: London, UK, 2012.

36. Huber, A.; Mayer, I.; Beillan, V.; Goater, A.; Trotignon, R.; Battalgini, E. Refurbishing Residential Buildings. A Socio-Economic Analysis of Retrofitting Projects in Five Countries. 2011. Available online: http:/ / fedarene. org/documents/pro-jects /EEW2/WSED2011/Huber.pdf. (accessed on 23 March 2019).

37. Lisin, E.; Kindra, V.; Strielkowski, W.; Zlyvko, O.; Bartkute, R. Economic Analysis of Heat and Electricity Production in the Decentralisation of the Russian Energy Sector. Transform. Bus. Econ. 2017, 16, 75-89. 
38. Fawcett, T.; Killip, G.; Janda, K. Building expertise: Identifying policy gaps and new ideas in housing eco-renovation in the UK and France. In Proceedings of the ECEEE 2013 Summer Study, Belambra Les Criques, France, 3-8 June 2013; pp. 339-350.

39. Novikova, A.; Vieider, F.; Neuhoff, K.; Amecke, H. Drivers of Thermal Retrofit Decisions: A Survey of German Single- and Two-Family Houses (CPI Report); Climate Policy Initiative Berlin: Berlin, Germany, 2011.

40. Chang, M.-C.; Shieh, H.-S. The Relations between Energy Efficiency and GDP in the Baltic Sea Region and Non-Baltic Sea Region. Transform. Bus. Econ. 2017, 16, 235-248.

41. Nair, G.; Gustavsson, L.; Mahapatra, K. Factors influencing energy efficiency investments in existing Swedish residential buildings. Energy Policy 2010, 38, 2956-2963. [CrossRef]

42. Stiess, I.; Zundel, S.; Deffner, J. Making the home consume less-Putting energy e ciency on the refurbishment agenda. ECEEE 2009 Summer study. Act! Innovate! Deliver. In Proceedings of the ECEEE 2009 Summer Study; European Council for an Energy Efficient Economy: Stockholm, Sweden, 2009; pp. 1821-1827.

43. Cadima, P.S.P. Retrofitting Homes for Better Energy Performance: E occupants' perspective. In Proceedings of the PLAE 2009-26th Conference on Passive and Low-Energy Architecture, Quebec, QC, Canada, 22-24 June 2009.

44. Better Buildings Partnership. Low Carbon Retrofit Toolkit; The Building Centre: London, UK, 2010.

45. De T'Serclaes, P. Financing Energy Efficient Homes. Existing Policy Responses to Financial Barriers; IEA Information Paper; IEA: Paris, France, 2007.

46. De T'Serclaes, P.; Jollands, N. Mind the Gap. Quantifying Principal-Agent Problems in Energy Efficiency; International Energy Agency: Paris, France, 2007.

47. Dabija, A.-M. Rehabilitation of Mass Dwellings in Romania. A Critical Approach. Sci. Bull. Electr. Eng. Facul. 2010, 10, 40-45.

48. Owens, S.; Driffill, L. How to change attitudes and behaviours in the context of energy. Energy Policy 2008, 36, 4412-4418. [CrossRef]

49. IEA. Promoting Energy Efficiency Investments. Case Studies from the Residential Sector; International Energy Agency and Agence Francaise de Development: Paris, France, 2008.

50. Sorrell, S.; O'Malley, E.; Schleich, J.; Scott, S. The Economics of Energy Efficiency-Barriers to Cost-Effective Investment; Edward Elgar: Cheltenham, UK, 2004.

51. Vainio, T. Building renovation-A new industry? In Proceedings of the Conference on Management and Innovation for a Sustainable Built Environment, Amsterdam, The Netherlands, 20-23 June 2011.

52. Nikola, N. Effect of Pipe Repairs on Housing Prices. Master's Thesis, Aalto University, Greater Helsinki, Finland, 2011.

53. Bouzarovski, S. Energy poverty in the European Union: Landscapes of vulnerability. Wiley Interdiscip. Rev. Environ. 2013, 3, 276-289. [CrossRef]

54. Bouzarovski, S.; Petrova, S. A global perspective on domestic energy deprivation: Overcoming the energy poverty-fuel poverty binary. Res. Soc. Sci. 2015, 10, 31-40. [CrossRef]

55. Moore, R. Definitions of fuel poverty: Implications for policy. Energy Policy 2012, 49, 19-26. [CrossRef]

56. Hernández, D.; Bird, S. Energy Burden and the Need for Integrated Low-Income Housing and Energy Policy. Poverty Public Policy 2010, 2, 5-25. [CrossRef] [PubMed]

57. IIBW. Implementation of European Standards in Romanian Housing Legislation: Final Report. 2008. Available online: http:/ / www.rabo.org.ro/wp-content/uploads / RHL-Final-Report-080129-en.pdf. (accessed on 23 March 2019).

58. Heiskanen, E.; Matschoss, K.; Kuusi, H.; Lapillone, B.; Sebi, C.; Mairet, N.; Zahradník, P.; Atanasiu, B.; Zangheri, P.; Georgiev, Z.; et al. Working Paper: Literature Review of Key Stakeholders, Users and Investors D2.4. of WP2 of the Entranze Project; IEE: Brussels, Belgium, 2012.

59. Rittel, H.W.J.; Webber, M.M. Dilemmas in a general theory of planning. Policy Sci. 1973, 4, 155-169. [CrossRef]

60. Ritchey, T. Wicked Problems—Social Messes. Decision Support Modelling with Morphological Analysis; Springer: Berlin/Heidelberg, Germany, 2011.

61. Galvin, R. Integrating the rebound effect: Accurate predictors for upgrading domestic heating. Build. Res. Inf. 2015, 43, 710-722. [CrossRef]

62. Christensen, T.H.; Gram-Hanssen, K.; Adjei, A.; de Best-Waldhober, M. Energy renovation practices in Danish homes: The influence of energy labels on home renovation practices. In Proceedings of the 10th Conference of the European Sociological Association (esa2011): Social Relations in Turbulent Times, Geneva, Switzerland, 7-10 September 2011. 
63. Lemon, M.; Wright, A.J.; Cook, M.B.; Crilly, M.; Shaw, D. Retrofitting Homes for Energy Efficiency: An Integrated Approach to Innovation in the Low-Carbon Overhaul of UK Social Housing. Energy Environ. 2012, 23, 1027-1055.

64. Organ, S.; Proverbs, D.; Squires, G. Motivations for energy efficiency refurbishment in owner-occupied housing. Struct. Surv. 2013, 31, 101-120. [CrossRef]

65. Killip, G. Products, practices and processes: Exploring the innovation potential for low-carbon housing refurbishment among small and medium-sized enterprises (SMEs) in the UK construction industry. Energy Policy 2013, 62, 522-530. [CrossRef]

66. Risch, C.A. Evaluation of the impact of environmental public policy measures on energy consumption and greenhouse gas emissions in the French residential sector. Energy Policy 2012, 46, 170-184.

67. Sirombo, E.; Filippi, M.; Catalano, A.; Sica, A. Building monitoring system in a large social housing intervention in Northern Italy. Energy Procedia 2017, 140, 386-397. [CrossRef]

68. Janda, K.B.; Parag, Y. A middle-out approach for improving energy performance in buildings. Build. Res. Inf. 2013, 41, 39-50. [CrossRef]

69. Janda, K.B.; Killip, G.; Fawcett, T. Reducing Carbon from the "Middle-Out": The Role of Builders in Domestic Refurbishment. Buildings 2014, 4, 911-936. [CrossRef]

70. Healy, J.D. Housing, Fuel Poverty, and Health: A Pan-European Analysis; Ashgate Publishing: Aldershot, UK, 2004.

71. Markandya, A.; Steimikiene, D. Efficiency and Affordability Considerations In The Pricing of Energy for Households. Econ. J. Dev. Issues 2003, 3, 1-14.

72. Banfi, S.; Farsi, M.; Filippini, M.; Jakob, M. Willingness to pay for energy-saving measures in residential buildings. Energy Econ. 2008, 30, 503-516. [CrossRef]

73. Horne, R.; Dalton, T. Transition to low carbon? An analysis of socio-technical change in housing renovation. Urban Stud. 2014, 51, 3445-3458. [CrossRef]

74. Gohardani, N.; Klintberg, T.A.; Björk, F. Turning building renovation measures into energy saving opportunities. Struct. Surv. 2015, 33, 133-149. [CrossRef]

75. Patterson, J.L. Evaluation of a Regional Retrofit Programme to Upgrade Existing Housing Stock to Reduce Carbon Emissions, Fuel Poverty and Support the Local Supply Chain. Sustainability 2016, 8, 1261. [CrossRef]

76. Paiho, S.; Abdurafikov, R.; Hoang, H.; Kuusisto, J. An analysis of different business models for energy efficient renovation of residential districts in Russia cold regions. Sustain. Cities Soc. 2015, 14, 31-42. [CrossRef]

77. Bell, C.J.; Nadel, S.; Hayes, S. On-Bill Financing for Energy Efficiency Improvements: A Review of Current Program Challenges, Opportunities and Bets Practices (Report Number E118); American Council for an Energy-Efficient Economy (ACEEE): Washington, DC, USA, 2011; Available online: http:/ / www.aceee.org/sites/default/ files/publications/researchreports/e118.pdf (accessed on 14 November 2013).

78. Würtenberger, L.; Bleyl, J.W.; Menkveld, M.; Vethman, P.; van Tilburg, X. Business Models for Renewable Energy in the Built Environment. 2012. Available online: http:/ /iea-retd.org/wp-content/uploads/2012/ 04/RE-BIZZ-final-report.pdf (accessed on 14 August 2013).

79. Johnson, K.; Willoughby, G.; Shimoda, W.; Volker, M. Lessons learned from the field: Key strategies for implementing successful on-the-bill financing programs. Energy Effic. 2012, 5, 109-119. [CrossRef]

80. Boute, A. Modernizing the Russian district heating sector: Financing energy efficiency and renewable energy investments under the New Federal Heat Law. Pace Environ. Law Rev. 2012, 29, 746-810.

81. Ozarisoy, B.; Altan, H. Adoption of Energy Design Strategies for Retrofitting Mass Housing Estates in Northern Cyprus. Sustainability 2017, 9, 1477. [CrossRef]

82. Bertoldi, P.; Rezessy, S.; Vine, E. Energy service companies in European countries: Current status and a strategy to foster their development. Energy Policy 2006, 34, 1818-1832. [CrossRef]

83. Brounen, D.; Kok, N.; Quigley, J.M. Residential energy use and conservation: Economics and demographics. Eur. Econ. Rev. 2012, 56, 931-945. [CrossRef]

(C) 2019 by the authors. Licensee MDPI, Basel, Switzerland. This article is an open access article distributed under the terms and conditions of the Creative Commons Attribution (CC BY) license (http:/ / creativecommons.org/licenses/by/4.0/). 